\title{
On Farm Benefits of the Chickpea in Rajasthan with Reference to Gangour (GNG 1581) Variety
}

\author{
Keshav Kumar*1, Vikram Yogi ${ }^{2}$, Madhu Sharma ${ }^{3}$ and Mukesh Kumar ${ }^{4}$
}

${ }^{1}$ Ph.D. Scholar, Department of Agricultural Economics, MPUAT, Udaipur, Rajasthan, India

${ }^{2}$ Assistant Professor, Department of Agricultural Economics College of Agriculture, SKRAU, Bikaner, Rajasthan, India

${ }^{3}$ Head of Dept., Department of Agricultural Economics College of Agriculture, SKRAU, Bikaner, Rajasthan, India

${ }^{4}$ Ph.D. Scholar, Department of Agricultural Economics College of Agriculture, SKRAU, Bikaner, Rajasthan, India

*Corresponding author: aggarwalkeshav123@gmail.com (ORCID ID: 0000-0002-5993-4380)

Received: $14-09-2020$

Revised: 21-11-2020

Accepted: 09-12-2020

\begin{abstract}
Chickpea (Cicer arientinum) is known in India since ancient times, and In Asia and Europe chickpea is said to be one of the oldest pulses known and cultivated. The On farm Benefits of the chickpea in Rajasthan with reference to Gangour (GNG, 1581) variety was evaluated in this study. The evaluation was based on a household survey of chickpea grower in 4 villages of Bikaner District of Rajasthan. To evaluate on farm benefits of the chickpea in Rajasthan with reference to Gangour (GNG, 1581) variety the cost of cultivation concept and simple statistical tools were used. Extra revenue generation estimated is ₹ 760 crores per year in case of Gangour (GNG, 1581) variety. Labor productivity was higher for Gangour (GNG, 1581) (0.74q/day), and lower for the local variety (0.44q/day).

Highlights

(0 Cost concept was used given by CACP to evaluate the varietal impact of Gangour (GNG, 1581) and local cultivars of chickpea.

( On farm benefits such as (productivity, net income, labour productivity) are compared between Gangour (GNG, 1581) and local cultivars.
\end{abstract}

Keywords: On farm Benefits, Cost of cultivation, Cost of production, Labor productivity, Revenue generation

Chickpea (Cicer arientinum) is known in India since ancient times. Globally, chickpea is the third most important pulse crop in production, next to dry beans and field pea (FAO, 2011). Chickpea is an important legume that plays an important role in the food and nutritional security of people in the developing countries contributing to protein intake, mainly for the vegetarian population. In comparison to other pulses, Chickpea is a rich source of carbohydrates and protein, both constituting about $80 \%$ of the total dry seed mass (Chibbar et al. 2010; Geervani, 1989). Chickpea is cholesterol free and is a rich source of vitamins, dietary fibre and minerals (Wood and Grusak, 2007). Chickpea contain $23 \%$ protein, $64 \%$ carbohydrates, $47 \%$ starch,
$5 \%$ fat, $6 \%$ crude fiber, $6 \%$ soluble sugar and 3\% ash (Aykroyd and Doughty, 1982). As a leguminous crop it improve soil fertility by fixing atmospheric nitrogen into the soil. This property has an added benefit to farmers by cutting external applications of nitrogenous fertilizers and in turn cuts cost of production and thus is environment friendly crop. South and Southeast Asia contributes about 81 per cent to the world chickpea production, with India as the principal chickpea producing nation $(84 \%$

\footnotetext{
How to cite this article: Kumar, K., Yogi, V., Sharma, M. and Kumar, M. (2020). On Farm Benefits of the Chickpea in Rajasthan with Reference to Gangour (GNG 1581) Variety. Economic Affairs, 65(4): 633-636.

Source of Support: None; Conflict of Interest: None (क) क
} 
share in the region). The area under the chickpea, marginally expended from 6.4 million ha to 9.19 million ha during the period 2000-01 to 2010-11. However, the production expanded substantially from 5.47 to 8.22 million tonnes due to the rise in grain yields from $853 \mathrm{~kg} / \mathrm{ha}$ to $895 \mathrm{~kg} / \mathrm{ha}$ (Reddy and Reddy, 2010).

Inspite of large area and production there are many constraints of area, production and productivity in India as well as in Rajasthan. The area of pulses does not expand remarkably as compare to wheat and rice. Totally 3.2 million tones of additional pulses can be produced by extending pulses area to rainfed rice fallow lands, replacing low productive crops and summer fallows (Inabasekar, 2014).

It includes various constraints such as non availability of high yielding seeds, insufficient knowledge of package and practice, a less input use, insufficient irrigation facilities and it is mostly depended on rains, insufficient fertilizers and minerals use. Among the other yield attributing input available in chickpea cultivation, seed of improved variety, is one of the important factors for increasing productivity. Through use of superior varieties existing once in yielding ability, the ultimate aim of chickpea growers is to get higher remunerative income (Umrathiya, 2015).

So, there is need to develop a high yielding variety which can grow in rain fed condition and give more profitability to farmers. Therefore, present study was done to evaluate varietal impact and on farm benefits of chickpea with reference to Gangour variety (GNG 1581) and compared with local cultivars. ARS, Shree Ganganagar of SKRAU, Bikaner has developed 'Gangour (GNG 1581)' variety of chickpea under AICRP (All India Coordinated Research Project) which is very popular in the chickpea growing area and gradually replacing all existing varieties (Local/Traditional).

\section{MATERIALS AND METHODS}

Both primary and secondary data were used in the study. The primary data was collected through well structured, pre-tested and comprehensive schedules from 120 chickpea growers in Rajasthan. Secondary data was collected from different government agencies like Rajasthan state seed and organic certification agency and area, production and yield was collected from different secondary sources, therefore Rajasthan state purposively selected, In Rajasthan, Bikaner district was selected as it has highest production under chickpea cultivation. Then, two tehsil were selected on the basis of highest production. From each selected tehsil, two villages were chosen randomly. From each of the village, 15 farmers were interviewed growing Gangour (GNG 1581) variety of chickpea and 15 growing local/ traditional variety. Thus, a total of 120 farmers were selected for this study. Simple statistical methods were used to calculate extra revenue generated by the Gangour (GNG 1581) variety. Cost of cultivation was calculated by Cost concept given by CACP (Commission for Agricultural Costs and Prices. The different income measurement also use for estimating different income level.

\section{RESULTS AND DISCUSSION}

\section{Evaluation of on farm benefits}

The on-farm benefits of improved chickpea varieties accruing to the sample farmers of villages were assessed. It was observed that Gangour (GNG, 1581 ) variety yield was greater than that of local or traditional chickpea variety. This was much high. Table 1 shows that the seed distribution of Gangour (GNG, 1581) variety seed continuously increasing and the area under the variety is also continuously increasing. This indicates that the area under the Gangour (GNG, 1581) variety is continuously expanding. Table 1 shows that adoption of Gangour (GNG, 1581) variety was gradually increasing by replacing previous existing local/traditional variety (Shiyani et al. 2002).

Table 1: Distribution of certified chickpea Gangour (GNG 1581) variety seed in Rajasthan

\begin{tabular}{lll}
\hline Year & $\begin{array}{l}\text { Seed Distributed } \\
(\mathbf{q})\end{array}$ & $\begin{array}{l}\text { Area under Gangour } \\
\text { (GNG 1581)(ha) }\end{array}$ \\
\hline $2009-10$ & 0 & \\
$2010-11$ & 30374.00 & 37967.50 \\
$2011-12$ & 21646.00 & 27057.50 \\
$2012-13$ & 10000.00 & 12500.00 \\
$2013-14$ & 87587.68 & 109484.60 \\
$2014-15$ & 73863.62 & 92329.53 \\
$2015-16$ & 98931.18 & 123664.00 \\
$2016-17$ & 186747.98 & 233435.00 \\
\hline
\end{tabular}


Table 2: On-farm benefits of improved chickpea varieties to sample farmer's villages

\begin{tabular}{|c|c|c|c|c|c|c|c|}
\hline Variety & $\begin{array}{l}\text { Yield } \\
\text { (q) }\end{array}$ & $\begin{array}{l}\text { Price } \\
(₹ / q)\end{array}$ & $\begin{array}{l}\text { Gross Return } \\
\text { (₹/ha) }\end{array}$ & $\begin{array}{l}\text { Cost } \\
\text { (₹/ha) }\end{array}$ & $\begin{array}{l}\text { Net income } \\
(₹ / h a)\end{array}$ & $\begin{array}{l}\text { Unit Cost } \\
(₹ / q)\end{array}$ & $\begin{array}{l}\text { Labour Productivity } \\
\text { (q/day) }\end{array}$ \\
\hline $\begin{array}{l}\text { Gangour } \\
\text { (GNG 1581) }\end{array}$ & $17.70^{* * * *}$ & 4030 & 76668.00 & 32068.10 & 44599.90 & 1811.75 & 0.74 \\
\hline Local & 10.65 & 4035 & 46029.50 & 30535.43 & 15494.07 & 2867.18 & 0.44 \\
\hline
\end{tabular}

Independent ${ }^{* * *} 1 \%$ level of significant.

The Table 2 shows that higher yield of Gangour (GNG, 1581) variety of chickpea resulted in a decline in per unit cost of production and an increase in profitability levels than the local variety.

Every enterprise can't be judge without the test of profitability. The net income over variable cost of Gangour (GNG, 1581) variety of chickpea varieties was ₹ 44599.90/ha. The corresponding value for the local variety was only ₹ $15494.07 /$ ha. The Table 2 shows that additional yield and income of $7.05 \mathrm{q} /$ ha and ₹ 29105.83/ha, respectively, were obtain from the Gangour (GNG, 1581) variety (Tripathi et al. 2002).

Another benefit of Gangour (GNG, 1581) variety was higher labor productivity. Average labor productivity was higher for Gangour (GNG, 1581) $0.74 q /$ day, followed by local variety $0.44 q /$ day showing that Gangour (GNG, 1581) variety of chickpea utilized labor more effectively than local variety (Shiyani et al. 1998).

Fig. 1 shows the generation of extra marketable surplus which was another benefit derived from the cultivation of Gangour (GNG, 1581) variety. Fig. 2 presents the proportion of the marketable surplus of Gangour (GNG 1581) and local chickpea varieties among the sample households. The marketable surplus of those growing Gangour (GNG, 1581) was higher $(89.44 \%)$. For those who grow local varieties, the marketable surplus was as lower (83.49\%). Relatively more marketable surplus of Gangour (GNG, 1581) was expected as the variety has atrait with a higher productivity. Therefore, farmers sell greater quantities of this variety in the market. The locally preferred variety has lower productivity to meet consumption requirements. It may be inferred from this analysis that the Gangour (GNG, 1581) chickpea cultivars have a positive impact on the economy of the farmers in the study areas (Shiyani (2001), (Ortiz-Ferrara et al. 2007).

\section{Extra revenue Generated by Gangour (GNG, 1581) variety}

Estimation of the extra revenue was calculated by simple mathematical calculation as follow:

Approximate area under the Gangour (GNG, 1581) variety $=\mathrm{A}$

Average incremental superiority of Gangour (GNG, 1581) over old chickpea varieties/local $=\mathrm{P}$

Extra production of chickpea variety by using this variety $Y=A \times P$

Extra revenue generated using chickpea variety Gangour (GNG 1581) (per annum) $=Y \times($ MSP of chickpea)

Production of Gangour (GNG, 1581) variety seed $(2016-17)=18674798 \mathrm{~kg}$

Seed rate of Gangour (GNG, 1581) variety $($ Recommended $)=80 \mathrm{~kg} / \mathrm{ha}$

Estimated area of Gangour (GNG, 1581) variety= Production of seed/ recommended seed rate

$$
\begin{aligned}
& =18674798 / 80 \\
& =233434.98 \mathrm{ha}
\end{aligned}
$$

Incremental yield per ha with the variety Gangour over local variety $=7.05 \mathrm{q}$

Incremental yield if total estimated area is under Gangour (GNG, 1581) Variety 233434.98 ha at an average production of $7.05 \mathrm{q} / \mathrm{ha}=233434.98 \times 7.05$ $=1645716.61 \mathrm{q}$

Extra revenue generated at MSP of $₹ 4620 / \mathrm{q}=$ $1645716.61 \times 4620=₹ 7603210738.20$

The extra revenue estimated by the production of Gangour (GNG, 1581) variety was ₹ 760 crore during 2016-17 which shows the superiority of the Gangour (GNG, 1581) variety over other local variety (Tiwari et al. 2020). 
In spite of its positive impact this variety also have the negative impacts. This variety requires more water than other local variety. So, when the water needed not available will affect its productivity. This variety is also more sensitive to pest attacks.

\section{CONCLUSION}

The On farm Benefits of the chickpea in Rajasthan with reference to Gangour (GNG, 1581) variety was evaluated in this study. We were found major finding of this study that the adoption of Gangour (GNG, 1581) variety was gradually increasing by replacing a previously existing local/traditional variety. The study shows that the additional productivity and income were much higher with respect to Gangour (GNG, 1581) variety. The labour productivity was also higher with respect to Gangour (GNG, 1581) variety than other traditional variety. There was also the much higher production of extra revenue with reference to Gangour (GNG, 1581) variety than other local/traditional varieties.

\section{REFERENCES}

Aykroyd, W.R. and Doughty, J. 1982. Legumes in human nutrition. Food and Agriculture Organization of the United Nations. FAO food and nutrition paper, 20: 1.

Chibbar, R.N. Ambigaipalan, P. and Hoover, R. 2010. Molecular diversity in pulse seed starch and complex carbohydrates and its role in human nutrition and health. Cereal Chemistry, 87(4): 342-352.

FAO, F. 2011. Available online at: http://faostat. fao. org/ site/291/default. aspx. Food and Agriculture Organization.

Geervani, P. 1989. Utilization of chickpea in India and scope for novel and alternative uses. Uses of Tropical Grain Legumes, 27: 47.

Inbasekar, K. 2014. Pulse Production in India: Challenges and Strategies. Economic Affairs, 59: 403-414.
Ortiz, R., Trethowan, R., Ferrara, G.O., Iwanaga, M., Dodds, J.H., Crouch, J.H. and Braun, H.J. 2007. High yield potential, shuttle breeding, genetic diversity, and a new international wheat improvement strategy. Euphytica, 157(3): 365-384.

Reddy, A. and Reddy, G.P. 2010. Supply side constrains in production of pulses in India: Case study of lentils. Agricultural Economics Research Review, 23: 129-136.

Shiyani, R.L., Joshi, P.K. and Bantilan, M.C.S. 2001. Impact of chickpea research in Gujarat. International Crops Research Institute for the Semi-Arid Tropics.

Shiyani, R.L., Joshi, P.K., Asokan, M. and Bantilan, M.C.S. 2002. Adoption of improved chickpea varieties: KRIBHCO experience in tribal region of Gujarat, India. Agricultural Economics, 27(1): 33-39.

Shiyani, R.L., Joshi, P.K., Asokan, M., Bantilan, M.C.S. and Sethi, S.C. 1998. Adoption of improved chickpea varieties in Panchmahals district of Gujarat. Assessing joint research impacts. In Proceedings of an International workshop on joint impact Assessment of NARS/ICRISAT Technologies for the Semi-Arid Tropics. International Crops Research Institute for The Semi Arid Tropics, Andhra Pradesh (India).

Tiwari, U., Sekar, I., Anbukkani, P., Bisen, J., Kumar, P., Jha, G.K. and Kumar, P. 2020. Economic Impact of Vegetable Variety in Haryana: A Case of Pusa Rudhira of Carrot. Indian Journal of Economics and Development, 16(1): 147-151.

Tripathi, A.K. and Das, S.K. 2002. Economics of improved chickpea (Cicer arietinum L.) Technology in Kymore and Satpura hills of M.P. Indian Journal of Hill Farming, 15(1): 35-38.

Umretiya, K.A. 2015. Comparative Study on Adoption of Improved Chickpea Varieties in Indore District of Madhya Pradesh (Doctoral dissertation, RVSKVV, Gwalior (MP).

Wood, J.A. and Grusak, M.A. 2007. Nutritional value of chickpea. In Chickpea Breeding and Management, pp. 101-142 [Yadav, S.S., Redden, R., Chen, W. and Sharma, B. editors]. Wallingford: CAB International. 